\title{
Breast-feeding and weaning patterns in Benghazi, Libyan Arab Jamahiriya
}

Nuri M. Shembesh,' Nura Naseb M. Balo ${ }^{2}$ and Ratan Singh ${ }^{3}$

$$
\begin{aligned}
& \text { أنماط الإرضاع من الثدي والفطام في بثغازي بالمباهيرية العرية الليية }
\end{aligned}
$$

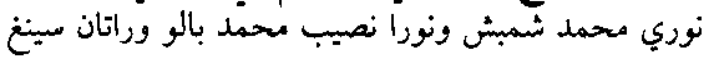

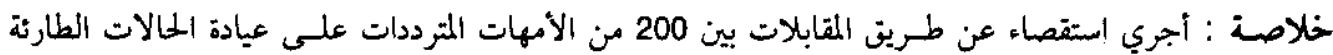

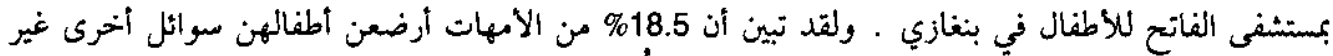

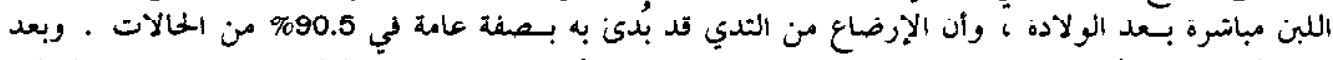

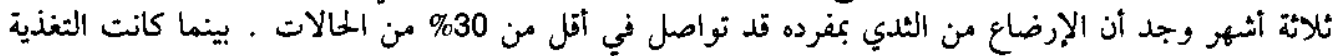

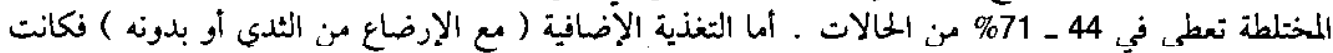

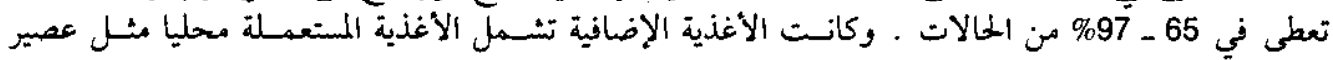

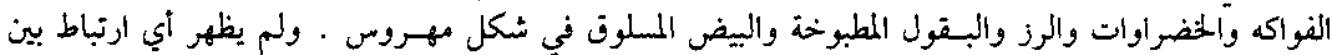

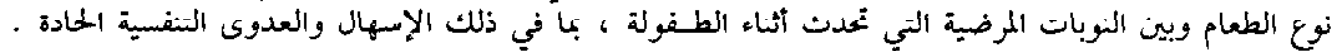

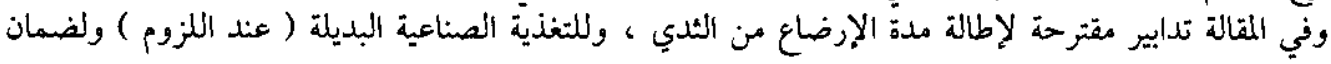

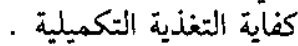

ABSTRACT An interview survey of 200 mothers attending the emergency service of Al-Fateh Paediatric Hospital, Benghazi, showed that prelacteal feed was given to $18.5 \%$ of babies and breast-feeding was ever initiated in $90.5 \%$. After three months exclusive breast-feeding was continued in less than $30 \%$, mixed feeding in $44 \%-71 \%$ and supplementary feeding (with and without breast-feeding) in $65 \%-97 \%$. Locally consumed food like fruit juice, vegetables, cooked rice and cereals and boiled eggs in mashed form were used as supplementary foods. No association was revealed between tho type of feeding and childhood episodes of any illness, including diarrhoea or acute respiratory infection. Measures for prolonged breast-feeding, substitute artificial feeding (when indicated) and supplementary feeding are suggested.

Les pratiques en matière d'allaitement maternel et de sevrage à Benghazi, Jamahiriya arabe libyenne

RESUME Une enquête par interrogations réalisée auprds de 200 mères qui co rendent au sorvico dos urgences de l'Hópital pédiatrique Fateh de Benghazi a montré que le lait colostral était donné aux nourrissons dans $18,5 \%$ cas et que l'allaitement matemel était mis en route dans tous les cas pour $90,5 \%$ d'entre eux. Après une période de trois mois, l'allaitement maternel exclusif était poursuivi dans moins de $30 \%$ des cas, l'alimentation mixte dans $44-71 \%$ des cas et l'alimentation d'appoint (avec ou sans allaitement maternel) dans $65-97 \%$ des cas. Les aliments consommés au niveau local tels que les jus de fruit, les légumes, le riz et les céréales cuites ainsi que les oeufs réduits en purée étaient utilisés comme aliments d'appoint. Ausoun lien n'a pu ôtro ótabli ontro lo modo d'alimontation ot loc ópicodoe de maladie, notamment de diarrhée ou d'infection respiratoire aiguë pendant la petite enfance. Des mesures en faveur de l'allaitement maternel prolongé, de l'allaitement artificiel de substitution (si indiqué) et de l'alimentation d'appoint sont suggérées.

'Department of Paediatrics; ${ }^{2}$ Department of Laboratory Medicine and Genetic Research Unit;

'Department of Community Medicine, Al-Arab Medical University, Faculty of Medicine, Benghazi, Libyan

Arab Jamahiriva.

Received: 18/02/97; accepted: 04/05/97

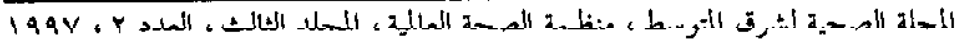




\section{Introduction}

Breast-feeding is one of the oldest practices, recommended in the Holy Quran, Biblical records and ancient Hindu scriptures [l.2]. However, there has been increasing concern in recent years about the changing pattern of breast-feeding, particularly in societies in rapid transition [3-7]. Data from 86 countries revealed that there are very large differences in breast-feeding practice between countries, between population groups within counties and within different groups over a period of time [4]. A downward trend in breast-feeding has been noted in widely differing countries of the Middle East, especially in urban areas where mothers with raised socioeconomic status resort to bottle-feeding quite early [6-8]. Over the past three decades, the Libyan Arab Jamahiriya has undergone such a rapid socioeconomic transformation that the practice of breast-feeding was likely to be influenced. An earlier study in Benghazi in 1981 showed that only $54.8 \%$ of mothers breast-fed for more than 6 months [9]. Reassessment was considered essential to have the factual knowledge of the current situation, and to recommend measures for prolonged breast-feeding to substitute artificial and supplementary feeding.

\section{Subjects and methods}

Renghazi is the second largest city and its population has grown more than 10 times, from 60000 in 1984 to 632466 in January 1992. During 1991 there were 15928 live births of which $50.7 \%$ were males. More than $95 \%$ of births took place at Al-Jamahiriya Maternity Hospital, Benghazi. The infant mortality rate in 1991 was 57.6 per 1000 live births.
Al-Fateh Paediatric Hospital in Benghazi is a teaching hospital for Al-Arab Medical University, and has been serving Benghazi and surrounding areas since 1968 for outdoor and indoor medical care services. During 1992, a total of 7048 children were admitted, of whom $58 \%$ were males and $42 \%$ females.

The present study was conducted dur ing the period from 1st June to 31 st August 1992 , and included 200 consecutive babies attending outdoor emergency services for the first time with mild to moderate illness. A senior house surgeon interviewed the mothers using a pretested questionnaire regarding prelacteal, breast, artificial and supplementary feeding at various periods for babies ranging in age from 1 month to 24 months. Of the 200 babies, 128 (64\%) were males. By age, $124(62 \%)$ were under six months, $64(32 \%)$ were between 6 and 12 months and $12(6 \%)$ were more than 12 months. The variables under investigation included prelacteal feeds, breast-feeding, artificial feeding and supplementary foods.

\section{Results}

Observations have been presented in tabular form. Table 1 shows introduction of prelacteal feeds, breast-feeding, artificial feeding and supplementary food along with age and sex of the babies. Table 2 shows mode of feeding according to baby's age in months. Table 3 shows the type of supplementary foods used and Table 4 depicts childhood illness in relation to type of fecding. 
Table 1 Biological and feeding characteristics of children at Al-Fateh Paodiatric Hospital, Benghazi, 1992

\begin{tabular}{|c|c|c|}
\hline Variable & No. & $\%$ \\
\hline \multicolumn{3}{|l|}{$\operatorname{sex}$} \\
\hline Total & 200 & 100.0 \\
\hline Male & 128 & 64.0 \\
\hline Female & 72 & 36.0 \\
\hline \multicolumn{3}{|l|}{ Present age (in months) } \\
\hline$<3$ & 28 & 14.0 \\
\hline $3-5$ & 49 & 24.5 \\
\hline $6-9$ & 40 & 20.0 \\
\hline $10-12$ & 40 & 20.0 \\
\hline $13-24$ & 43 & 21.5 \\
\hline \multicolumn{3}{|l|}{ Use of prelacteal feed } \\
\hline Glucose water & 27 & 13.5 \\
\hline Honey/gammela & 10 & 5.0 \\
\hline None & 163 & 81.5 \\
\hline \multicolumn{3}{|c|}{$\begin{array}{l}\text { Time of introducing breast- } \\
\text { feeding after birth }\end{array}$} \\
\hline$<12$ hours & 130 & 65.0 \\
\hline $12-23$ hours & 11 & 5.5 \\
\hline $24-47$ hours & 12 & 6.0 \\
\hline $48-71$ hours & 11 & 5.5 \\
\hline $72-95$ hours & 4 & 2.0 \\
\hline $90-120$ hours & 10 & 6.5 \\
\hline None (feeding artificial) & 19 & 9.5 \\
\hline \multicolumn{3}{|c|}{ Age of starting artificial feeding } \\
\hline Birth & 19 & 9.5 \\
\hline$<1$ month & 49 & 24.5 \\
\hline $1-3$ months & 68 & 34.0 \\
\hline $4-6$ months & 18 & 4.0 \\
\hline $7-9$ months & 6 & 3.0 \\
\hline $10-12$ months & 1 & 0.5 \\
\hline Not yat & 39 & 19.5 \\
\hline \multicolumn{3}{|c|}{$\begin{array}{l}\text { Age of introduction of } \\
\text { supplementary solid foods }\end{array}$} \\
\hline$<3$ months & $5(28)^{a}$ & 17.0 \\
\hline 3-5 months & $32(49)^{\circ}$ & 65.3 \\
\hline $6-9$ months & $33(40)$ & 82.5 \\
\hline $10-12$ months & $39(40)$ & 97.5 \\
\hline 13-24 months & $40(43)$ & 93.0 \\
\hline
\end{tabular}

Note. Brackets include total number of children in each age grouy

\section{Discussion}

Of 200 consecutive children included in the study $128(64 \%)$ were males and $72(36 \%)$ were females. These proportions were similar to those of admissions. It is noted that the proportion of male children being admitted to the hospital (58\%) was significantly higher than ohserved among live births (51\%) in Benghazi during 1992. No definite causes for this are known, but further investigation of factors such as higher male susceptibility or male sex preference, is needed on a prospective basis.

\section{Prelacteal feeds (Table 1)}

In the study group $37(18.5 \%)$ infants were given prelacteal feeds in the form of glucose water, honey or gammela (extract of the leaves of an indigenous plant mixed with sugar and water). It was encouraging to note that the proportion of prelacteal feeds had dramatically fallen from $94 \%$ in $1979(9)$ to its current level.

\section{Time of initiation of breast-feeding (Table1)}

Although a large number of babies (65.0\%) were put to the breast within 12 hours of birth, for $25.5 \%$ it was delayed by 12 to 120 hours. Another $9.5 \%$ of children were bottle-fed from birth. There was a definite change towards earlier starting of breastfeeding compared to only $2.8 \%$ within 12 hours in 1979 [9]. However, it is highly desirable that breast-feeding should be initiated as soon after birth as possible, preferably within the first half an hour. In order to facilitate this, the practice of rooming-in should be adopted in maternity hospitals.

\section{Duration of breast-feeding}

Although $90.5 \%$ of mothers started with exclusive breast feeding (Table 1), yet at 
Table 2 Mode of feeding by baby's age, Benghazi, 1992

\begin{tabular}{lcccccccc}
\hline $\begin{array}{l}\text { Baby's age } \\
\text { (months) }\end{array}$ & \multicolumn{2}{c}{$\begin{array}{c}\text { Breast- } \\
\text { feeding }\end{array}$} & \multicolumn{2}{c}{$\begin{array}{c}\text { Artificial } \\
\text { feeding }\end{array}$} & \multicolumn{2}{c}{$\begin{array}{c}\text { Mixed } \\
\text { feeding }\end{array}$} & \multicolumn{3}{c}{ Total } \\
& No. & $\%$ & No. & $\%$ & No. & $\%$ & No. & $\%$ \\
\hline$<3$ & 7 & 25.9 & 0 & 29.6 & 12 & 44.4 & 27 & 100 \\
$3-6$ & 5 & 10.4 & 5 & 10.4 & 38 & 79.2 & 48 & 100 \\
$7-9$ & 7 & 17.9 & 8 & 20.5 & 24 & 61.5 & 39 & 100 \\
$10-12$ & 9 & 21.9 & 3 & 7.3 & 29 & 70.7 & 41 & 100 \\
$13-24$ & 11 & 24.4 & 3 & 6.7 & 31 & 68.9 & 45 & 100 \\
All ages & 39 & 19.5 & 27 & 13.5 & 134 & 67.0 & 200 & 100 \\
\hline
\end{tabular}

Note. Percentages are out of total children in each age group

Table 3 Type of food material used as supplementary fond by 140 mothore in Benghazi, 1992

\begin{tabular}{lrr}
\hline Food & \multicolumn{2}{c}{ Mothers } \\
& No. & $\%$ \\
\hline Fresh fruits and vegetables & 108 & 72.5 \\
Rioo & 97 & 65.1 \\
Eggs & 84 & 56.4 \\
Cereals & 83 & 55.7 \\
Meat & 36 & 24.2 \\
Almond & 11 & 7.4 \\
Commercial foods & 27 & $\mathbf{1 8 . 1}$ \\
\hline
\end{tabular}

Note. Total responses were 446 because more than one type of tood was used by most mothers

any subsequent age the proportion was only one-quarter or Icss. Mixed feeding (breast plus artificial) was practised by most mothers $(61.5 \%$ to $79.2 \%$ ) starting from 4 months to 24 months after birth.

Exclusive artificial feeding remained the mode for between $6.7 \%$ and $20.5 \%$ after 3 months of agc. The miajurity or mothers fed their babies on demand without regard for interval or frequency. In the present study artificial feeding, with or without breast-feeding, was introduced by 34. $0 \%$ of mothers within 1 month, and also by $34.0 \%$ within 3 months (Table 1). The source of milk supply for artificial feeding was stated as market by $84 \%$ of mothers, dairy farm by $13 \%$ and free gift from maternal and child health centre by $3 \%$. In 1979 a higher proportion of younger and low parity mothers had often fed their babies artificially than had older and high parity women [9]. The two age-groups of younger and older mothers probably represented two different cohorts, and in future the rate of artificial feeding if not checked was likely to increase along with the entry of more younger women to the motherhood pool.

Our results are similar to those reported earlier from Benghazi, Sudan, Saudi Arabia and other developing countries $[3,8,9,10,11]$. In Saudi Arabia, the duration of breast-feeding was associated with maternal characteristics, family income, type of defivery and use of contraceptives [3]. Similar changes were anticipated among Libyan women in the near future.

\section{Supplementary foods}

In the study supplementary food included all meals given to the child besides breast- 
Table 4 Childhood illness: experience and type of feeding in Benghazi, 1992.

\begin{tabular}{|c|c|c|c|c|c|}
\hline Childhood illnoss & $\begin{array}{l}\text { Broast- } \\
\text { feeding }\end{array}$ & $\begin{array}{l}\text { Mixed } \\
\text { feeding }\end{array}$ & $\begin{array}{l}\text { Artiticial } \\
\text { feeding }\end{array}$ & No. & $\%$ \\
\hline All cases & 39 & 134 & 27 & 200 & 100 \\
\hline \multicolumn{6}{|l|}{ Any illness (episodes) } \\
\hline 0 & 13 & 21 & 5 & 39 & 19.5 \\
\hline 1 & 12 & 56 & 7 & & \\
\hline 2 & 7 & 29 & 10 & & \\
\hline 3 & 2 & 8 & 1 & & \\
\hline $4-6$ & 5 & 20 & 4 & & \\
\hline 1 or more & 26 & 113 & 22 & 161 & 80.5 \\
\hline Mean per child & 1.46 & 1.78 & 1.85 & & \\
\hline \multicolumn{6}{|l|}{ Diarrhoea episodes } \\
\hline 0 & 10 & 58 & 14 & 88 & 44.0 \\
\hline 1 & 11 & 40 & 7 & & \\
\hline 2 & 7 & 18 & 2 & & \\
\hline 3 & 4 & 8 & 2 & & \\
\hline $4-6$ & 1 & 10 & 2 & & \\
\hline 1 or more & 23 & 76 & 13 & 112 & 56.0 \\
\hline $\begin{array}{l}\text { Mean diarrhoea } \\
\text { episodes per child }\end{array}$ & 1.10 & 1.12 & 1.00 & & \\
\hline \multicolumn{6}{|l|}{ Acute respiratory infection } \\
\hline Yes & 10 & 40 & 8 & 58 & 29.0 \\
\hline No & 29 & 94 & 19 & 142 & 71.0 \\
\hline Mean attack per child & 0.26 & 0.30 & 0.30 & & \\
\hline
\end{tabular}

milk, cow's milk powder and fresh mammalian milk. Babies who were being given supplementary foods amounted to $17.9 \%$ for those who were below 3 months of age, $65.4 \%$ were from 3 months to 5 months, $82.5 \%$ from 6 months to 9 months and $97.5 \%$ between 10 and 12 months (Table 1). In the Benghazi study, $38.4 \%$ of infants were given supplementary foods before 6 months of age [9]. In Khartoum, Sudan, supplementary food was introduced by $76 \%$ to $91 \%$ of mothers before 6 months of age [3]. The timing of supplementary foods is of critical importance for the health and well-being of the child. On the one hand, before 6 months, breast-feeding offers general protection to children from diarrhoeal disease and other infections. In addition, delay in introduction of other foods offers some protection. On the other hand, after 4-6 months, growth cannot be sustained on breast milk alone. According to WHO, the International Paediatric Association and other bodies, introduction of supplementary foods should commerce at $4-6$ months of age.

The supplementary foods commonly used by mothers in the study (Table 3 ) included fresh fruits and vegetables, rice, eggs, cereals, meat, almond and commercial foods [12]. The purpose of supplementary food is to transfer the child from breast milk to family diet. Cultural influence plays a major role in the decision about which 
foods are to be introduced and at what age. The supplementary food practices have been surveyed in most of the Arab countries $[5,11,12]$. The general pattern in the present study is largely the same as in corresponding socioeconomic strata.

\section{Childhood illness}

Children who had any illness in general, diarrhoea or acute respiratory tract infections accounted for $80.5 \%, 56.0 \%$ and $71.0 \%$ respectively (Table 4 ). However, no statistically significant difference was observed between the type of feeding and childhood illness experience. No reason is known, yet recall bias and small sample size wide coverage by safe water supply, better personal and community hygiene and other conditions could be possible factors for such results.

Further investigations are needed to confirm the association, if any, between the type of feeding and occurrence of illness, diarrhoca and acute respiratory infections.

\section{Comments and recommendations}

In this study of mothers of 200 babies attending Al-Fateh paediatric hospital emergency services were interviewed regarding child feeding practices. The data showed that although $90 \%$ of mothers started with breast-feeding, artificial feeding with or without breast-feeding was introduced early by a large number of women. Most babies commenced with fruits and vegetables, rice, eggs, cereals, almonds and commercial foods.

Taking the factors in the present study and the Libyan situation into consideration, implementation of the following recommendations is suggested:
1. Medical personnel, from consultants to primary health care workers, need specific training in the management of breast-feeding, overcoming lactational problems and in weaning techniques.

2. Hospital practice Inust be changed so that babies are roomed-in and put on the breast within half an hour of birth.

3. Health education about breast-feeding should be strengthened through health institutions, voluntary organizations and mass media.

4. Promotion of breast-feeding should be a major goal of all health personnel. At the same time, the importance of fresh mammalian milk and commercial formulas as valuable nutritional supplements, and in certain circumstances as effective replacements of human milk when essentially needed, should not be ignored.

5. Establishment of breast-feeders associations at the community level, where mothers can teach each other the techniques of successful breast-feeding, is required.

6. Creation of favourable attitudes and conditions is suggested for working women to breast-feed in the place of work.

7. Infant-milk companies should direct their promotional activities at physicians and not at the public. Advertisement of breast-milk substitutes must be banned.

8. In addition to the breast or artificial feeding, supplementary foods rich in proteins and other nutrients consisting of mainly locally produced/consumed foods should be introduced twice a day starting from 4 months of age and 2-4 times a day from 6 months of age.

9. Weaning should normally be started by 12 months, using all foods consumed 
by the family 4 to 6 times a day, and should be completed between 18 and 24 muniths.

10. Infant and child feeding practices need to be monitored to initiate intensified education campaigns at an early sign of deterioration of breast-feeding prevalence and duration.

\section{Acknowledgements}

The authors sincerely thank the rotating house officers for helping in collection of information and the mothers for their cooperation and patience during interview.

\section{References}

1. Brim CJ in Medicine in the Bible. New York, Faroben Press, 1963.

2. Venkata Chalam PS, Rubello IM. Nutrition for mother and child. Indian Council of Medical Research, Special Report, Series 41, 1971.

3. Al-Sokait MA. A ctudy of the faotore influencing breast-feeding patterns in Saudi Arabia. Saudi medical journal. 1988, g(6):596-601

4. Omer MIA et al. Breast-feeding and weaning in Sudan. Journal of tropical paediatrios, 1087, 33: 2-12.

5. Patwardhan VN, Darby WJ. Infant feeding practice. In: The state of nutrition in the Arab Middle East. Nashville: Vanderbllt University Press, 1972, 182-91.

6. Prevalence and duration of breast-feeding: a critical review of available information. World health quarterly, 1982, 35: 92-116.

7. Balo NN, Shembesh NM, Singh R. Maternal characteristics and infant and young child feeding in Benghazi. Eastern Mediterranean healt journal, 1997, 2(3): 432-9.

8. Hartouche JK. Breast-feeding patterns: a review of studies in the Eastern Mediterranean Region. Alexandria, World Health Organization, Eastern Mediterranean Regional Office, 1982 (EMRO Technical Publications Series, No.4).

9. Abudejaja A, Singh R, Khan MAU. Infant feeding practices in north-eastern region of Libyan Arab Jamahiriya. Garyounis medical journal, 1982, 5(1):29-36.

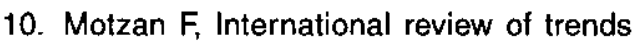
in infant feeding in developing countries. Paediatrics, 1984, 4:648-66 (suppl).

11. Serenius $F$ et al. Patterns of breast-feeding and weaning in Saudi Arabia. Acta paediatrica, 1988, 316: 121-9, (suppl).

12. Popkin BM, Bilsborrow RF, Akin JS. Breast-feeding patterns in low income cuuntries. Science, 1982, 218:1088-93. 